\title{
PENGEMBANGAN MEDIA ICT BERBASIS GAME BARE-TRICK PADA MATERI BARISAN DAN DERET DI KELAS IX MTS NURUL MUBTADIIN
}

\author{
Rosita Dwi Ferdiani*1, Yuniar Ika Putri Pranyata ${ }^{2}$, Luluk Qomariyah ${ }^{3}$ \\ 1,2,3 Universitas Kanjuruhan Malang \\ rositadf@unikama.ac.id*1, yuniar.mat@unikama.ac.id ${ }^{2}$, \\ lulukqomariyah5@gmail.com ${ }^{3}$ \\ *Corresponding Author
}

Received 20 April 2020; revised 26 August 2020; accepted 23 September 2020.

\begin{abstract}
ABSTRAK
Penelitian ini bertujuan untuk mengembangkan media ICT berbasis Game Bare-trick berdasarkan aspek kevalidan, kepraktisan, dan keefektifan. Penelitian ini menggunakan model pengembangan ADDIE. Tahapan pengembangan media ini yakni: (1) Analysis (2) Design (3) Development (4) Implementation (5) Evaluation. Penelitian ini melibatkan 30 peserta didik kelas IX MTs Nurul Mubtadiin sebagai subyek uji coba media, serta dosen dan guru sebagai ahli validator media. Angket validasi digunakan oleh ahli media, ahli materi, dan ahli pembelajaran untuk menguji kevalidan, angket respon untuk menguji kepraktisan dan tes hasil belajar untuk menguji keefektifan media. Hasil penelitian berdasarkan aspek kevalidan menurut ahli media, ahli materi dan ahli pembelajaran menunjukkan, media memiliki nilai sangat valid dengan presentase masing masing adalah 93,1\% dari ahli media, 92\% ahli materi, dan 97,5\% menurut ahli pembelajaran. Aspek kepraktisan dilakukan pengujian berdasarkan angket respon pada uji lapangan terbatas dengan jumlah 10 peserta didik dan menunjukkan media ini termasuk kategori sangat praktis dengan presentase 91,8\%. Aspek keefektifan diperoleh hasil tes belajar yang menunjukkan 24 peserta didik mencapai nilai KKM (Kriteria Ketuntasan Minimal), dan diperoleh ketuntasan 78,8\%. Hal ini menunjukkan bahwa media ini termasuk kategori efektif. Dapat disimpulkan bahwa media ICT Berbasis Game Bare-trick layak sebagai media pembelajaran karena memenuhi kevalidan, kepraktisan dan keefektifan.
\end{abstract}

Kata kunci: barisan dan deret, game bare-trick, media ICT

\section{ABSTRACT}

This study aims to develop ICT media based on Game Bare-tricks which is aspects of validity, practicality, and effectiveness. This study uses ADDIE development model. The stages of 
this media development which include: (1) Analysis (2) Design (3) Development (4) Implementation (5) Evaluation. This study involved 30 students of class IX MTs Nurul Mubtadiin as subjects of media trials, as well as lecturers and teachers as experts of media validator. Validation questionnaires are used by media experts, materials experts, and learning experts to verify validity, response questionnaires are to test practicality and test results is to examine the effectiveness of the media. The results of the study based on the validity aspects according to media experts, material experts and learning experts showed that the media had very valid values with each percentage being $93.1 \%$ of media experts, $92 \%$ of materials experts, and $97.5 \%$ of learning experts. The practicality aspect is examined based on the response questionnaire in a limited field test with a total of 10 students and shows that media is a very practical category with a percentage of $91.8 \%$. The effectiveness aspect was obtained by the results of the learning test which showed that 24 students achieved the KKM score (Standart of Minimum Completeness of Mastery Learning), and $78.8 \%$ of completeness was obtained. This shows that that media is an effective category. It can be concluded that ICT media based on Game Bare-trick is appropriate as a learning media because it iseligible in terms of validity, practicality and effectiveness.

Keywords: sequence and series, game Bare-trick, ICT media

\section{PENDAHULUAN}

Saat ini Indonesia tengah memasuki era revolusi industri 4.0 atau sering disebut dengan era digital. Bila ingin bersaing di era digital ini, Indonesia perlu segera meningkatkan kemampuan dan keterampilan sumber daya manusia melalui pendidikan (Syamsuar \& Reflianto, 2016). Karena dengan pemanfaatan teknologi informasi dan komunikasi dapat menggeser proses pembelajaran dari teacher centered menjadi student centered (Kurdi, 2009). Menurut Sutarman (dalam Kurniawati \& Sutirman, 2017) dengan adanya bantuan komputer dan teknologi informasi, maka dapat meningkatkan kualitas pendidikan. Salah satu faktor yang mempengaruhi kualitas pendidikan adalah tenaga pendidik. Tenaga pendidik dituntut untuk selalu meningkatkan profesionalitasnya untuk tetap kratif dan inovatif, maka diperlukan suatu pendukung proses untuk mencapai tujuan pembelajaran. Pembelajaran yang dimaksud bisa terwujud apabila suasana pembelajarannya diciptakan dengan menyenangkan (Mintasih, 2016). Trend in International Mathematics and Science Study (TIMMS) yang dilansir oleh Puspendik (2015) menyatakan bahwa secara umum peserta didik Indonesia lemah di semua aspek konten maupun kognitif, baik untuk matematika dan sains. Kelemahan yang dialami dikarenakan kesulitan belajar, dimana pembelajaran 
yang sering diterapkan oleh pendidik di Indonesia masih bersifat teacher centered dan berpusat pada buku, sehingga peserta didik merasa bosan dan tidak bertarik untuk belajar matematika. Oleh karena itu, inovasi media pembelajaran akan memberikan kesan yang berbeda pada peserta didik, sehingga dapat membangun suasana kelas yang aktif, interaktif dan menarik.

Perkembangan teknologi informasi dewasa ini telah mampu mengemas kondisi dan realitas pembelajaran menjadi lebih menarik dan memberikan pengondisian secara adaptif dalam proses pembelajaran dimanapun berada, serta penggunaan teknologi dalam pembelajaran pun lebih efektif dibanding pembelajaran yang konvensional (Panggayudi, Suweleh, \& Ihsan, 2017). Dalam penggunaannya, terdapat beberapa model pembelajaran berbantuan komputer yang menarik, salah satunya adalah model permainan (games) (Darmawan, 2012). Game menjadi salah satu solusi inovatif pada pembelajaran di era revolusi industri 4.0 ini.

Berdasarkan hasil observasi peneliti pada tanggal 2 Oktober 2019 di MTs Nurul Mubtadiin yang terletak di Jalan Arjuna, Kecamatan Purwodadi Kabupaten Pasuruan, bahwa proses pembelajaran yang dilakukan oleh tenaga pendidik mata pelajaran matematika masih belum menggunakan media pembelajaran yang dapat menunjang dalam penyampaian materi kepada peserta didik. Pendidik hanya menggunakan buku paket dalam proses belajar mengajar. Pendidik hanya fokus pada buku dan tugas yang ada pada media cetak, dan membiarkan peserta didik tidak memperhatikan penjelasan pendidik. Sehingga suasana dan kondisi kelas tidak dapat dikendalikan dengan baik.

Berdasarkan permasalahan tersebut, Game Bare-trick menjadi salah satu inovasi media pembelajaran di era revolusi industri 4.0. Game Bare-trick merupakan sebuah inovasi media pembelajaran yang dimainkan oleh peserta didik pada materi barisan dan deret, di dalam game tersebut terdapat materi dan soal evaluasi yang disesuaikan dengan Kompetensi Inti (KI) dan Kompetensi Dasar (KD). Menurut Kopoulos (dalam Panggayudi, Suweleh, \& Ihsan, 2017) menuturkan bahwa peserta didik akan memperoleh manfaat dari penggunaan game education dimana mereka akan merasa senang dan gembira dalam belajar matematika. Sesuai dengan tujuan penelitian ini, yakni antara lain 
mengembangkan media ICT berbasis Game Bare-trick pada materi barisan dan deret berdasarkan aspek kevalidan, kepraktisan dan keefektifan media.Selain itu, media ICT berbasis Game Bare-trick ini dapat menarik perhatian peserta didikdalam proses pembelajaran, sehingga proses pembelajaran yang terjadi bersifat student centered.

\section{METODE PENELITIAN}

Jenis penelitian yang digunakan adalah penelitian pengembangan dengan metode penelitian Research and Development $(R \& D)$ yaitu penelitian yang digunakan untuk menghasilkan produk tertentu dan menguji keefektifan produk tersebut (Sugiyono, 2014). Model pengembangan dalam penelitian ini adalah ADDIE. Model ini mempunyai 5 fase atau tahap utama yaitu Analisis (Analysis), Desain (Design), Pengembangan (Development), Implementasi (Implementation), dan Evaluasi (Evaluation). Adapun prosedur penelitiannya sebagai berikut:

1. Analisis (Analysis). Pada tahap ini dilakukan observasi kepada subjek dan objek penelitian. Observasi dilakukan di MTs Nurul Mubtadiin. Tahap analisis ini mencakup dua proses kegiatan, yaitu:

a. Analisis masalah; berdasarkan hasil pengamatan di ketahui permasalahan bahwa peserta didik merasa bosan dan monoton saat pembelajaran matematika.

b. Analisis komponen pembelajaran; analisis ini berkaitan dengan materi barisan dan deret yang disesuaikan dengan kurikulum, sehingga indikator pencapaian dan kompetensi materi barisan dan deret dapat terpenuhi.

2. Desain (Design). Berdasarkan hasil analisis, tahap selanjutnya adalah tahap desain atau perancangan produk yang meliputi:

a. Pengumpulan referensi; pengumpulan referensi ini bertujuan untuk mencari sumber yang relevan baik dari buku maupun internet seperti pengumpulan gambar, perancangan karakter game, pengumpulan referensi desain menu, animasi, dan referensi level game.

b. Perancangan isi materi; perancangan isi materi yakni berdasarkan Kompetensi Inti (KI) dan Kompetensi Dasar (KD). Pada perancangan isi 
materi Barisan dan Deret, peneliti mengaplikasikan materi dalam sebuah permainan atau game pada KD 3.14 dan 4.4.

c. Perancangan storyboard; storyboard berfungsi sebagai panduan untuk memudahkan pembuatan game. Dalam tahap ini, Peneliti merancang kerangka game yang meliputi alur cerita, level beserta isi Game Bare-trick.

3. Pengembangan (Development). Pada tahap ini dilakukan pembuatan media pembelajaran berbasis game dengan menggunakan Software Engine Unity. maka tahap selanjutnya yakni melakukan validasi kepada ahli materi, ahli media dan ahli pembelajaran atau praktisi/guru. Uji validitas digunakan untuk mengetahui kevalidan media yang selanjutnya dilakukan perbaikan atau revisi media.

4. Implementasi (Implementation). Tahap implementasi atau penerapan media pembelajaran kepada peserta didik dalam uji lapangan terbatas dilakukan oleh 10 peserta didik untuk mengetahui kepraktisan media dengan memberikan kuesioner, sedangkan 30 peserta didik dilihat dari hasil soal tes yang ada di dalam game guna untuk mengetahui uji keefektifan media.

\section{Uji Coba Produk}

Adapun uji coba produk dalam penelitian ini dapat diuraikan sebagai berikut:

1. Desain Uji Coba

Desain uji coba dalam penelitian ini dirancang dalam tiga tahap, yaitu tahap pertama adalah uji validitas oleh ahli media, ahli materi, dan ahli pembelajaran. Tahap kedua ada dua uji, yaitu

a. Uji coba terbatas. Uji terbatas ini dimaksudkan untuk mengetahui kepraktisan media. Menurut Alfiriani \& Ellbert (2017) siswa dibentuk dalam kelompok kecil kemudian mengisi angket respon kepraktisan yang telah disediakan. Peneliti melakukan uji coba terbatas yaitu dengan memberikan angket respon peserta didik untuk menguji kepraktisan media.

b. Uji coba lapangan luas. Tahap ini dimaksudkan untuk mengetahui keefektifan media. Menurut Alfiriani \& Ellbert (2017) pembelajaran secara klasikal untuk mengukur efektivitas terhadap hasil belajar siswa yang meliputi ranah kognitif yang diperoleh dari hasil tes kognitif sedangkan hasil belajar ranah psikomotor diperoleh dari lembar penilaian 
psikomotor siswa selama mereka praktek. Peneliti melakukan uji efektif dengan menilai hasil belajar peserta didik dalam uji lapangan luas.

2. Subyek Uji Coba

Subyek uji coba dalam penelitian pengembangan media pembelajaran berbasis game Bare-trick ini, yakni:

a. Peserta didik kelas IX MTs Nurul Mubtadiin sebanyak 10 orang sebagai subjek uji coba lapangan terbatas. Menurut Susilana \& Riyana (dalam Fajri, 2018) Jumlah uji kepraktisan untuk melihat respon peserta didik ini didasarkan pada jumlah evaluasi kelompok kecil yang ditulis didalam bukunya yang mana jumlah 10 orang merupakan jumlah yang dapat mewakili populasi target.

b. Seluruh peserta didik kelas IX MTs Nurul Mubtadiin sebanyak 30 orang sebagai subjek uji coba lapangan luas.

\section{Instrumen Pengumpulan Data}

Adapun instumen yang digunakan antara lain:

a. Lembar validasi media untuk ahli media. Lembar validasi media ini bertujuan untuk memperoleh penilaian terhadap media Game Bare-trick, yaitu berupa masukan dan saran untuk perbaikan atau revisi media.

b. Lembar validasi untuk ahli materi. Lembar validasi ini bertujuan untuk memperoleh penilaian terhadap penyampaian materi dalam media Game Baretrick.

c. Lembar validasi untuk ahli pembelajaran. Lembar validasi ini bertujuan untuk memperoleh penilaian tentang aspek pembelajaran dalam penggunaan media ICT berbasis Game Bare-trick

d. Angket respon kepraktisan. Menurut Alfiriani \& Ellbert (2017) Kepraktisan mengacu pada kondisi media yang dikembangkan mudah digunakan oleh pengguna (guru dan siswa) sehingga pembelajaran yang dilakukan bermakna, menarik dan menyenangkan dan berguna bagi kehidupan siswa, maka dalam hal ini dapat diketahui melalui lembar angket kepraktisan.

e. Tes hasil belajar peserta didik untuk menguji keefektifan. Menurut Alfiriani \& Ellbert (2017) Keefektifan dilihat dari tercapainya tujuan pembelajaran sehingga uji keefektifan adalah uji untuk melihat ketercapaian tujuan 
pembelajaran dengan menggunakan produk yang dikembangkan untuk proses pembelajaran. Penelitian ini menggunakan tes hasil belajar peserta didik ini digunakan untuk mengukur tingkat ketuntasan belajar peserta didik.

\section{Teknik Analisis Data}

Menurut Van den Akker dan Nieveen (dalam Rochmad 2012) menyatakan bahwa dalam penelitian dan pengembangan perlu memperhatikan kriteria kualitas. Untuk menguji kualitas kelayakan produk dengan memenuhi kriteria kevalidan, kepraktisan, dan keefektifan, maka kualitas produk dikatakan layak apabila memenuhi kriteria-kriteria berikut.

a) Analisis Kevalidan Media

Untuk menentukan tingkat kevalidan media pembelajaran menurut Purbasari, dkk (2012) dapat dilihat dari hasil persentasenya. Dalam penelitian ini bahwa media ICT berbasis Game Bare-trick pada materi barisan dan deret ini bersifat valid dan dapat diterapkan dalam proses kegiatan belajar mengajar matematika jika memiliki total persentase $70 \% \leq P<85 \%$.

b) Analisis Kepraktisan Media

Berdasarkan kriteria kepraktisan, maka media Game Bare-trick dikatakan praktis jika hasil persentasenya minimal $50 \% \leq X<85 \%$. Jika media tersebut praktis, maka dapat digunakan dengan sedikit revisi atau tanpa revisi.

c) Analisis Keefektifan Media

Media pembelajaran berbasis Game Bare-trick dikatakan efektif jika hasil jawaban peserta didik pada soal-soal yang ada di dalam Game Bare-trick dengan menunjukkan bahwa peserta didik mencapai Kriteria Ketuntasan Minimal (KKM) dengan nilai $\geq 75$. Berdasarkan analisis keefektifan media pada uji coba lapangan luas dikatakan efektif dengan melihat hasil tes soal peserta didik dengan melihat persentase rata-rata ketuntasannya.

5. Evaluasi (Evaluation). Evaluasi adalah proses untuk mengetahui media pembelajaran yang telah dibuat sesuai dengan yang diharapkan atau tidak. Selain evaluasi di akhir tahap ini pada dasarnya evaluasi juga telah dilaksanakan berupa evaluasi pengembangan dan evaluasi kevalidan produk yang dilakukan oleh ahli media dan ahli materi. Hasil evaluasi oleh ahli media dan ahli materi tersebut dijadikan sebagai dasar untuk melakukan perbaikan 
terhadap media pembelajaran yang telah dibuat. Evaluasi tentang kevalidan oleh guru matematika MTs Nurul Mubtadiin juga dapat digunakan sebagai dasar untuk menyempurnakan media yang telah dibuat.

\section{HASIL PENELITIAN DAN PEMBAHASAN}

Pengembangan media ICT berbasis Game Bare-trick ini dibuat dan dikembangkan berdasarkan model pengembangan ADDIE (Analysis, Design, Development, Implementation, dan Evaluation). Adapun hasil pengembangan media ini yakni berupa Game yang dibuat dengan aplikasi Software Engine Unity yang hasilnya akan disajikan dalam Gambar 1 sampai Gambar 18.

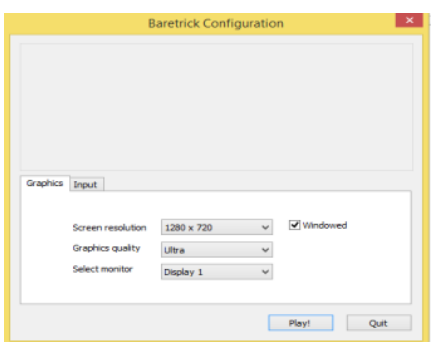

Gambar 1. Tampilan Resolusi Ukuran

Layar Game di Komputer

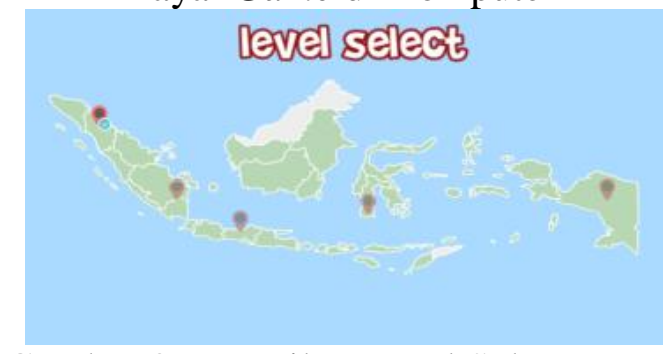

Gambar 3. Tampilan Level Select Game Bare-trick

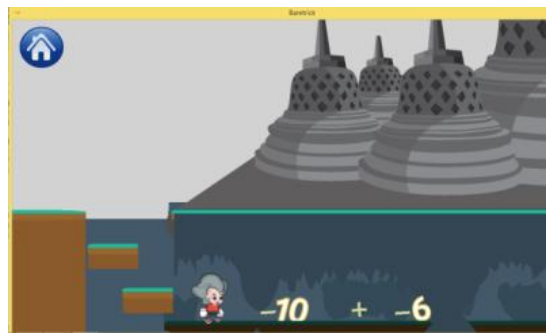

Gambar 5. Tampilan Soal di Level 2

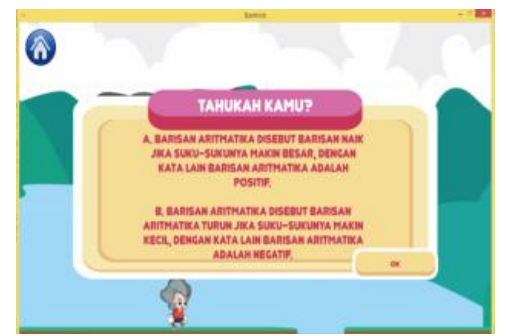

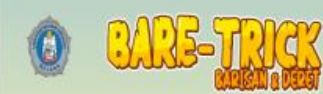

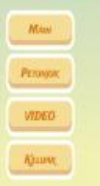

Gambar 2. Tampilan Menu Game Bare-trick

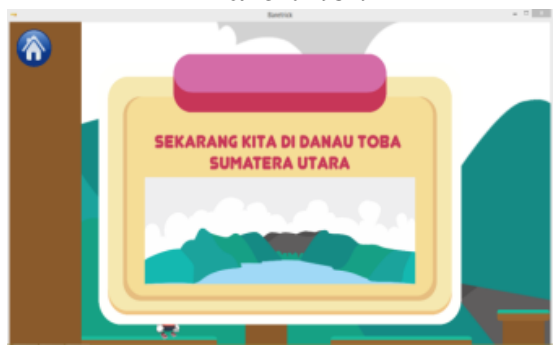

Gambar 4. Tampilan Level 1 di Sumatera Utara

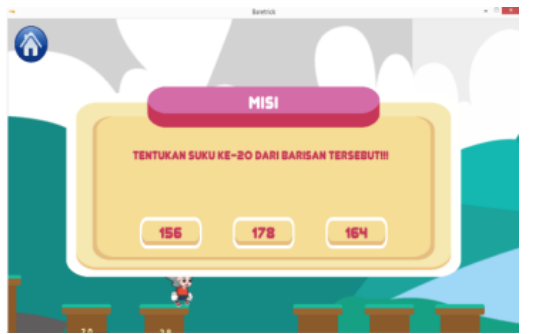

Gambar 6. Tampilan Soal Untuk Melengkapi Pijakan di Level 1

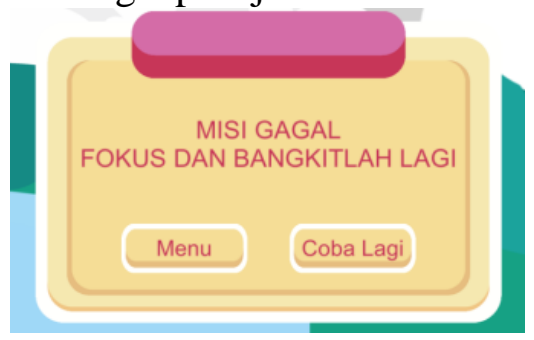


Gambar 7. Tampilan Materi

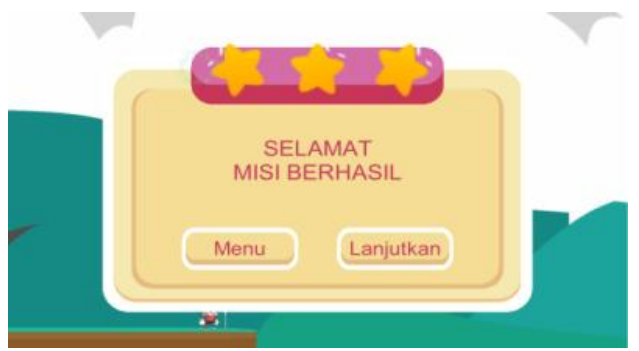

Gambar 9. Tampilan Ketika Misi di Salah Satu Level Berhasil

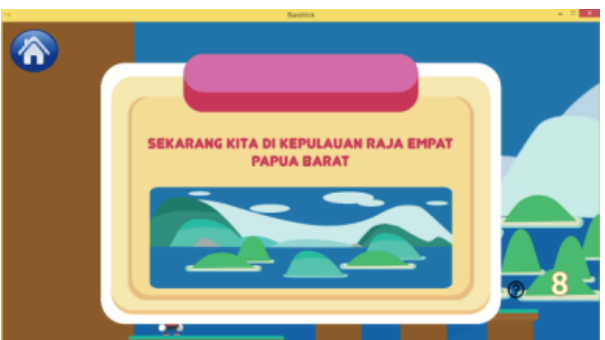

Gambar 11. Tampilan Level 3

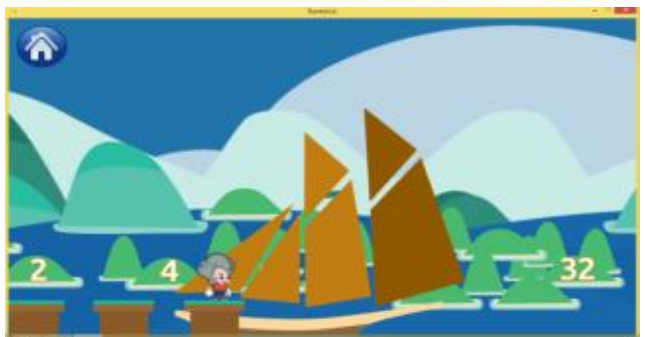

Gambar 13. Tampilan Ketika Level 3

Dapat Terlewati

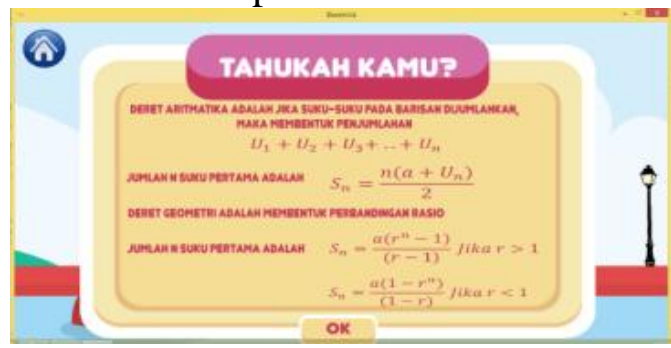

Gambar 15. Tampilan Materi

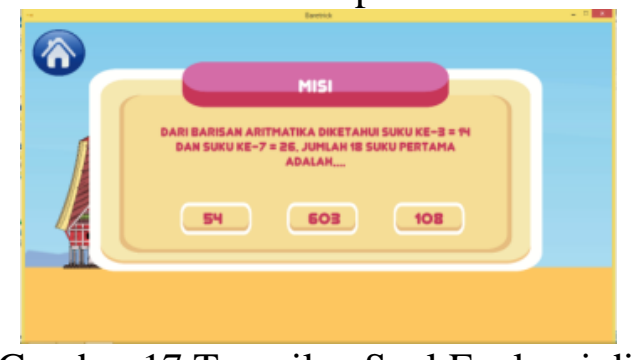

Gambar 17.Tampilan Soal Evaluasi di Level 5
Gambar 8. Tampilan Ketika Misi Gagal

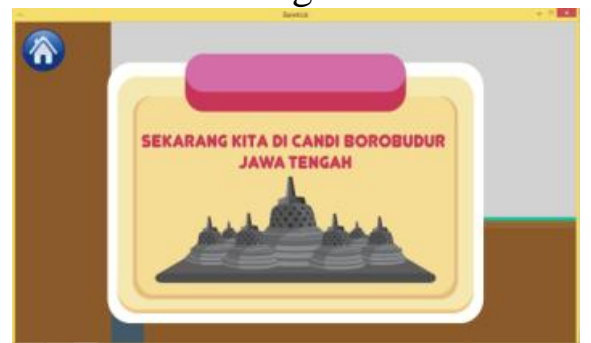

Gambar 10. Tampilan Level 2

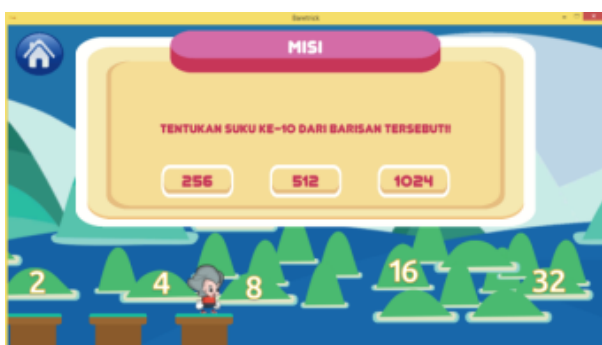

Gambar 12. Tampilan Soal di Level 3

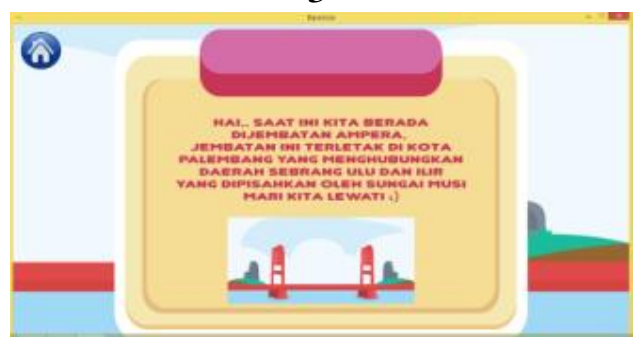

Gambar 14. Tampilan Level 4 di Jembatan Ampera

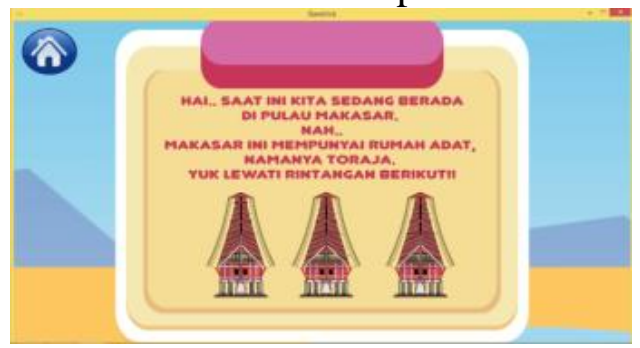

Gambar 16. Tampilan Level 5

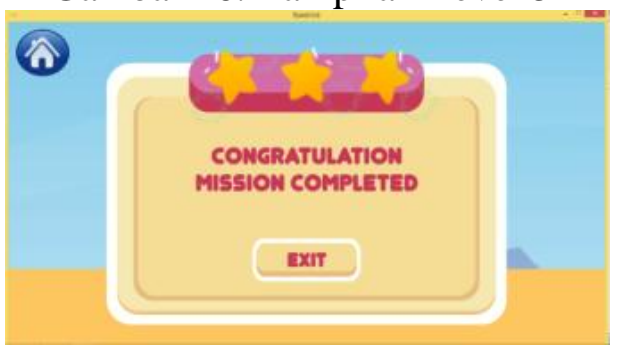

Gambar 18. Tampilan Ketika Semua Misi Berhasil 
Berdasarkan hasil penelitian yang dilakukan sesuai dengan model penelitian ADDIE, dan penelitian berdasarkan aspek kevalidan, kepraktisan, dan keefektifan media. Berikut ini merupakan hasil pengujian terhadap tiga aspek dan penyempurnaan produk.

a. Hasil Uji Kevalidan oleh Ahli Media

Uji kevalidan dilakukan dengan memberikan angket kepada ahli media, terdapat masukan atau saran yakni menambahkan kata "petunjuk" pada menu petunjuk penggunaan, masih ada bug yaitu ketika karakter masih tetap berjalan disaat muncul info pada level 4. Berdasarkan data yang didapat dari ahli validasi media diperoleh persentase total nilai sebesar 93,1\% dengan kategori "Sangat Valid".

b. Hasil Uji Kevalidan oleh Ahli Materi

Pada uji validasi ini, terdapat masukan atau saran yakni dalam memberikan latihan soal diharapkan menggunakan intruksi soal dengan aturan SPOK. Berdasarkan data yang di peroleh dari ahli materi dengan persentase total nilai sebesar 92\% dengan kategori "Sangat Valid".

c. Hasil Uji Kevalidan oleh Ahli Pembelajaran

Berdasarkan data yang didapat dari ahli pembelajaran diperoleh persentase total nilai sebesar 97,5\% dengan kategori "Sangat Valid”. Validasi yang dilakukan oleh ahli pembelajaran juga tidak terdapat komentar atau saran.

\section{Hasil Pengujian Pertama dan Revisi Produk}

Tahap uji coba ini dilakukan terhadap 10 anak di kelas IX dengan menggunakan angket respon kepraktisan media oleh peserta didik. Berdasarkan data yang diperoleh dari penilaian 10 peserta didik, dapat diketahui dari persentase untuk angket respon peserta didik yang menunjukkan rata-rata total sebesar 91,8\% dengan kategori "Sangat Praktis". Kategori ini berarti media ICT berbasis Game Bare-trick praktis dan dapat digunakan tanpa revisi. Pada uji lapangan terbatas ini tidak terdapat saran untuk perbaikan media dari peserta didik, karena sebagian besar dari peserta didik yang sudah menggunakan media ini menurutnya adalah sesuatu yang sangat menarik dan belum ditemui sebelumnya. Namun, terdapat beberapa komentar yang sama untuk menambah level, dalam hal ini peneliti memiliki keterbatasan dalam pembuatan game yakni 
terbatas pada 5 level.

\section{Hasil Pengujian Kedua dan Penyempurnaan Produk}

Tingkat keefektifan media diukur dengan hasil tes yang diberikan kepada peserta didik melalui media berbasis Game Bare-trick. Adapun hasil nilai peserta didik pada uji coba lapangan luas menunjukkan bahwa peserta didik mencapai KKM (Kriteria Ketuntasan Minimal) dengan nilai $\geq 75$ sebanyak 24 peserta didik dari 30 peserta didik. Dengan demikian persentase ketuntasan peserta didik sebesar 78,8 \% sehingga diperoleh nilai bahwa media ICT berbasis Game Baretrick efektif.

\section{SIMPULAN}

Berdasarkan hasil penelitian pengembangan media ICT berbasis Game Bare-trick pada materi barisan dan deret, dapat disimpulkan bahwa kelayakan media media ICT berbasis Game Bare-trick berdasarkan aspek kevalidan, kepraktisan dan keefektifan sebagai berikut,

1. Kevalidan media media ICT berbasis Game Bare-trick menurut ahli media sebesar 93,1\%, ahli materi 92\% dan ahli pembelajaran sebesar 97,5\%, hal ini menunjukkan bahwa media ini sangat valid.

2. Tingkat kepraktisan dilihat dengan menggunakan angket respon kepraktisan media pada uji lapangan terbatas oleh 10 peserta didik menunjukkan bahwa media ICT berbasis Game Bare-trick termasuk pada kategori sangat praktis dengan rata-rata skor pada uji coba lapangan terbatas $91,8 \%$

3. Tingkat keefektifan dilakukan pada uji coba lapangan luas yang diperoleh dari hasil tes belajar 30 peserta didik yang menunjukkan bahwa peserta didik yang mencapai KKM (Kriteria Ketuntasan Minimal) dengan nilai $\geq 75$ sebanyak 24 anak tuntas dan 6 peserta didik tidak tuntas dengan persentase $78,8 \%$ dan termasuk pada kategori efektif.

Berdasarkan penjelasan tersebut, media ICT Berbasis Game Bare-trick dapat dinyatakan sebagai media yang layak digunakan dalam proses pembelajaran matematika khususnya pada materi barisan dan deret karena telah memenuhi kriteria valid, praktis, dan efektif. 


\section{DAFTAR PUSTAKA}

Alfiriani, A., \& Ellbert, H. (2017). Kepraktisan dan keefektifan modul pembelajaran bilingual berbasis komputer. Jurnal Kependidikan, 1(1), 1223.

Darmawan, D. (2012). Pendidikan teknologi informasi dan komunikasi. Jakarta: Penerbit Andi.

Fajri, V. R., \& Lazulva. (2018). Desain media pembelajaran menggunakan software adobe flash professional Cs6 pada materi unsur transisi periode keempat. Journal of the Indonesian Society of Integrated Chemistry, 10(2), 28-41.

Kurdi, F. N. (2009). Penerapan student-centered learning dari teacher centered learning pada program studi penjaskes. Forum Kependidikan, 28(2), 108113.

Kurniawati, D., \& Sutirman. (2017). Pemanfaatan teknologi informasi dan komunikasi oleh perangkat desa gandulan kecamatan kaloran kabupaten temangagung. Jurnal Pendidikan Administrasi Perkantoran, 6(4), 374386.

Mintasih, D. (2016). Merancang pembelajaran menyenangkan bagi generasi digital. Jurnal el-Tarbawi, 9(1), 39-48.

Panggayudi, D. S., Suweleh, W., \& Ihsan, P. (2017). Media game edukasi berbasis budaya untuk pembelajaran pengenalan bilangan pada anak usia dini. MUST: Journal of Mathematics Education Science and Technology, 2(2), 255-266.

Purbasari, R. J., Kahfi, M. S., \& Yunus, M. (2012). Pengembangan aplikasi android sebagai media pembelajaran matematika pada materi dimensi tiga untuk siswa SMA kelas X. Jurnal Pendidikan Matematika, 1(2).

Puspendik. (2015). Hasil TIMSS 2015 diagnosis hasil untuk perbaikan mutu dan peningkatan capaian. Jakarta: Kemendikbud.

Rochmad. (2012). Desain pengembangan perangkat pembelajaran matematika. Journal Kreano, 3(1), 59-72.

Sugiyono. (2014). Metode penelitian kuantitatif, kualitatif dan $R \& D$. Bandung: Alfabeta.

Syamsuar, \& Reflianto. (2018). Pendidikan dan tantangan pembelajaran berbasis teknologi informasi di era revolusi industri 4.0. Journal Ilmiah Teknologi Pendidikan, 6(2), 1-13. 